\title{
LOETELUKATSE JA NIMEANDMISKATSE PSÜHHOLINGVISTIKA MEETODINA
}

\author{
Eelised ja kitsaskohad
}

MARI UUSKÜLA

$\mathrm{K}$

atseliste meetodite kasutamine on tänapäeval nii keeleteaduse kui ka üldisemalt humanitaar- ja sotsiaalteaduse oluline osa, ilma milleta suur hulk teadlasi oma igapäevaelu ette ei kujuta. Loetelukatset ja nimeandmiskatset on kasutatud erinevate semantiliste tähendusväljade uurimiseks kognitiivses lingvistikas ja psühholingvistikas (Majid jt 2011, 2015). Eestis on pikaaegne loetelukatsete tegemise traditsioon, mille edasiarendajaks võiks pidada Urmas Sutropit, kes võttis kasutusele nüüdseks nii lingvistikas kui ka teistes sotsiaal-ja humanitaarteadustes hästi tuntud kognitiivse esiletuleku indeksi (Sutrop 2001, 2011). Eesti keeles on loetelukatsega uuritud erinevaid semantilisi välju, mille hulka kuuluvad värvinimed (Sutrop 1995), värvinimed eesti viipekeeles (Hollman 2011), lõhnasõnad (Sutrop 1998; Zurbuchen 2017), temperatuurisõnavara (Sutrop 1998), emotsioonisõnavara (Vainik 2002, 2006), muusikainstrumendid (Eessalu 2012), elusloodus (Eessalu 2013), sugulussõnavara (Klemm 2013), kehaosad (Tiitson 2017) ja teised semantilised väljad. Uurijaid paelub loetelukatse lihtsus, mis võimaldab seda hõlpsalt välitöödel kasutada (Davies jt 1992), sest loetelukatset saab kasutada ka rahvaste juures, kes kõnelevad alles kaardistamisjärgus keeli.

Käesoleva artikli eesmärgiks on anda ülevaade loetelukatsest ja nimeandmiskatsest empiirilise meetodina ning välja tuua mõlema meetodi eelised ja puudused siinkirjutaja uurimis- ja katsete läbiviimise kogemusest lähtudes. Loetelukatses küsitakse katseisikutelt kõiki ühte semantilisse välja kuuluvaid sõnu, mis neile antud ajahetkel meenuvad. Nimeandmiskatse ongi tavaliselt pildile või muule stiimulile sõna, fraasi või lausega vastamine katses uuritavas keeles. Artiklist jääb välja temaatika, mis puudutab katsete tegemise vajalikkust või seda, kas eelistada introspektsiooni ja korpusanalüüsi katsete tegemisele, kuna seda on põhjalikult käsitlenud Jane Klavan, Ann Veismann ja Anni Jürine (2013). Nad viitavad tabavalt, et korpusanalüüs on keeleteaduses sageli esimeseks oluliseks sammuks ehk „teadusliku uurimistsükli esimeseks etapiks" ning uurija peaks olema nii julge, et astuda ka järgmine samm ja vähemalt proovima oma hüpoteesi ka katseliste meetodite abil kontrollida. Käesolev artikkel käsitleb loetelu- ja nimeandmiskatse tüüpi, mida Klavan jt on nimetanud vaba moodustuse katseks (2013: 22-23), kus katsealused on vabad kasutama keelt viisil, kuidas nad ise soovivad, st ilma oluliste piiranguteta. Uurija ülesandeks on tavaliselt talletada katseisikute öeldu nii, nagu katseisikud seda on esitanud, sest õigeid ja ebaõigeid vastuseid sellises katsetüübis ei ole. Ometi on ka loetelukatsel ja nimeandmiskatsel teatud piiranguid, millele on siiani suhteliselt vähe tähelepanu pööratud. Nende piirangute 
hulka võivad kuuluda semantilise üldmõiste puudumine keeles (Brindle 2016), stiimulite valikuga seotud piirangud, mis avalduvad alles materjali analüüsides (Uusküla, Eessalu 2018; Vejdemo 2017), stiimuli olek ning sellega seotud kirjeldamisraskused (Hollman 2011), kontekstiga seotud sõnakasutuse piirangud (Uusküla, Sutrop 2007; Eessalu, Uusküla 2013) jne.

Nii loetelukatset kui ka nimeandmiskatset on suhteliselt kerge läbi viia ning katsete tegemiseks ei vajata enamasti nõudlikku aparatuuri, piisab vaid uurija korralikust ettevalmistusest ja katseisikute kirjalikust nõusolekust. Tähtis on see, et kedagi ei värvataks ilma nõusolekuta katses osalema, seejuures tuleb olla ettevaatlik, millist infot katseisikutele anda ning mida mitte ette ära rääkida. Näiteks mängib semantilise mälu uurimisel olulist rolli spontaansus. Toome lihtsa näite. Kui öelda katseisikutele juba eelmisel õhtul või nädal aega ette, et küsitakse linnunimesid, otsivad katseisikuteks valitud inimesed üsna tõenäoliselt infot ja teadmisi lindude kohta enne uurijaga kohtumist. Nad täiendavad oma teadmisi selleks, et mitte rumalana näida, uurija aga ootab vahetut teadmist, millised linnunimed kuuluvad spontaanselt inimeste semantilisse mällu. Seega piisab uurijal ainult vajaliku info andmisest. Näiteks võib katseisikutele öelda, et uuritakse nende emakeelt ja keerulisi küsimusi ei esitata. Samuti abistab juba katse eel jagatud info, et õigeid ja valesid vastuseid pole, kedagi ei hinnata nende teadmiste põhjal ning saadud andmeid kasutatakse vaid üldistatud anonüümsel kujul. Kuigi loetelukatset saab läbi viia nii suulises kui ka kirjalikus vormis, peab uurija kindlasti silmas pidama, et vaid ühel viisil kogutud andmed on omavahel võrreldavad.

\section{Loetelukatse kui uurija esmane tööriist}

Loetelukatset võib küll pidada nii psühholingvistika, kognitiivse keeleteaduse kui ka antropoloogilise lingvistika tööriistaks, kuid samas on see meetod laialdast kasutust leidnud ka kognitiivteadustes, kultuuriantropoloogias, ühiskonnateadustes ja meditsiinilises diagnostikas. Näiteks võimaldab loetelukatse meetod kindlaks teha inimese semantilises mälus ehk mentaalses leksikonis aset leidvaid anomaaliaid, nt skisofreenia või Alzheimeri tõve korral (Aloia jt 1996; Chan jt 1997). Terminid semantiline mälu ja mentaalne leksikon viitavad samale nähtusele - inimese n-ö peas talletatud ja talletuvale infole ning seostele nende infokildude vahel. Mentaalne leksikon erineb oma struktuuri poolest kindlasti sõnaraamatute struktuurist, kus sõnad paiknevad tavaliselt kindlas, enamasti tähestikulises järjekorras: mentaalses leksikonis „talletatakse” sõnad seoste kaudu teiste sõnadega (Aitchison 1994: 10-11). Jean Aitchison toetub oma teoses mudelile, mis võrdleb sõnu ja sõnakogumeid linnadega, ning leiab, et nii nagu igal linnal on teise linnaga infovahetuseks mõeldud tunnelid, on sõnadel ja sõnakogumitel üksteisega teatud seosed (Aitchison 1994: 226). See mudel on siiski ilmselgelt primitiivne ning ei tasu arvata, et just nii inimmõistuses sõnu ja nendevahelisi seoseid töödeldaksegi, ometi sobib kirjeldus üsna hästi inimmeele mudelist abstraktse ettekujutuse saamiseks. Eelistatavalt võiks siiski kasutada terminit semantiline mälu, mis viitab veidi vähem sõnavarakogule või sõnaraamatule, seega kasutan siingi pigem terminit semantiline mälu kui mentaalne leksikon. 
Loetelukatse on üks lihtsamaid tööriistu uurija jaoks, kes soovib vaadata inimmõistuse sisse saamaks aru, millised sõnad meie teadvuses kokku kuuluvad ehk omavahel assotsiatsioonipaare moodustavad ${ }^{1}$ (lisaks vt Männik 2016). Loetelukatsega on võimalik välja selgitada ühe semantilise välja sõnad, mis millegi poolest keelekogukonna semantilises mälus ühe kategooria alla paigutatakse. Susan Weller ja Kimball Romney nimetavad neid sõnu ühe kultuurilise välja (ingl cultural domain) sõnadeks (1988: 10). Kuigi on olemas ka selliseid semantilisi välju, mille liikmed on alati muutumatud, nt nädalapäevade või kuude nimetused, on enamik siiski hägusate piiridega. Taolistesse semantilistesse väljadesse võib katseisikute antud vastuste põhjal sattuda ka sõnu, mis tunduvad uurijatele loeteludes üllatavad (vt nt Eessalu 2012). Seega on uurija ülesandeks vaadata oma materjali avatud pilguga, sest materjal võib sisaldada ootamatusi. Loetelukatse eeliseks on see, et uurija kasutab n-ö toormaterjali, mitte ei loo ise kategooriaid, mis võivad, aga ei pruugi kattuda katseisikute omadega. Nt ameerikainglise katseisikute puuviljade loetelusse on sattunud üllatuslikult ka tomat, kõrvits ja spargel (Weller, Romney 1988: 6), eluslooduse peamiste kategooriatena on aga keelejuhile meenunud järgmised semantilised väljad: loomad ja linnud, taimed ja vetikad ning putukad ja muud mutukad (Eessalu 2012). Juhul kui loetelukatset kasutatakse mingi taksonoomia rekonstrueerimiseks, nagu Martin Eessalu (2012) uurimuses, võib loetelukatse olla ka poolstruktureeritud intervjuu, kus uurija annab katseisikutele kätte juhtlõnga, mida nad edasi arendavad.

\section{Loetelukatse võimalused ja küsitavused}

Loetelukatse võimaldab meil teada saada, millised sõnad on sagedased ja meenuvad keelekõnelejatele esimestena ehk millised sõnad psühholoogiliselt esilduvad (Smith 1993; Sutrop 2001; Uusküla, Bimler 2016). Loetelukatses vaadatakse, kui sageli katseisikud mingit sõna loetlevad ja mitmendana nad sõna oma loeteludes nimetavad. Kognitiivset esilduvust saab arvutada erinevate indeksite abi, millest tuntuimad on juba eelnevalt nimetatud Sutropi kognitiivse esiletuleku indeks ehk KEI (Sutrop 2011: 56) ja Jerome Smithi vaba pikkusega loetelus esiletuleku indeks VPLEI (Smith 1993). KEI varieerub 1 ja 0 vahel: indeks saab 1 olla vaid juhul, kui kõik keelejuhid nimetavad ühte ja sama semantilise kategooria liiget alati esimesena (Sutrop 2011: 56). Sellist olukorda aga tegelikkuses peaaegu kunagi ei esine, sest katseisikute semantilises mälus paiknevad semantilise välja liikmed enamasti erinevas järjestuses. Sutropi KEI omapäraks on see, et iga semantilise välja esimesena nimetatud liikmed eristuvad teistest semantilise välja liikmetest märgatavalt (vt joonist 1). Lisaks on täheldatud, et kognitiivne esilduvus ja sagedus ei pruugi kokku langeda (Veismann 2008: 342-343), mida on näha igas loetelukatses (nt Uusküla 2007: 374 ja 378 joonis 2 soome värvinimede loetelukatse analüüsitulemuste kohta, kus värvisõnad punainen ja sininen eristuvad teistest värvinimedest kognitiivse esiletuleku indeksi põhjal märgatavalt). KEI-l on veel

1 Ene Vainik on viimastel aastatel kogunud hulgaliselt väärtuslikku materjali sõnaassotsiatsioonide kohta, mis on koondatud Eesti Keele Instituudis valmivasse assotsiatsioonisõnastikku (EKAS). 
seegi hea omadus, et tänu selle abstraktsusele ja parameetrite võrreldavusele on võimalik ühe semantilise välja indeksite võrdlus, nt Uusküla, Hollman ja Sutrop (2012: 64-65) võrdlevad viie soome-ugri keele - eesti, soome, ungari, udmurdi ja sürjakomi - ning eesti viipekeele kognitiivse esiletuleku indeksit, mis on arvutatud nende keelte värvinimede loetelukatsetega kogutud andmestike põhjal.

Loetelukatsega kogutud materjali analüüsides saab rakendada eri meetodeid. Värvide loeteludes ei järgi katseisikud mitte värvide spektraalset lähedust värviruumis, mida võiks spontaanselt eeldada, vaid värve loetletakse igas keeles väga minimaalsete kõrvalekalletega peaaegu samas järjestuses (Uusküla, Bimler 2016). Väikesed laiendused või kõrvalepõiked tavapärasest jadast ilmnevad alles liitsõnade või kultuurispetsiifiliste sõnade/mõistete loetlemisel. Multidimensionaalse skaleerimise meetodil (MDS) põhinevad semantilised kaardid (vt Uusküla, Bimler 2016), mida loetelukatse põhjal on võimalik koostada, toovad sellised mõisted hästi esile. Ühe kategooria kaardistamiseks alustavad katsealused kategooria prototüüpse esindaja nimetamisega. Värvinimede puhul on selliseks sõnaks pea kõikides keeltes punane. Seejärel liigub iga keelejuht edasi nn sõlmede juurde, mis seovad neid punasega, nt nimetatakse järgmisena värvisõnu sinine, kollane ja roheline, jätkatakse musta ja valgega, seejärel liigutakse aga sekundaarsete põhivärvinimede roosa, lilla ja oranž juurde, millele tavaliselt järgnevad veel tänu eesti keele produktiivsele sõnamoodustusele liitsõnad (nt heleroheline, samblaroheline, türkiissinine, tibukollane) ja kultuurispetsiifilised mõisted (nt potisinine) (vt Uusküla, Bimler 2016: 73). Nii jätkab iga katseisik kuni värvisõnavara ammendumise ning kategooria piiride hägustumiseni. Kategooria piiridel võime eesti keeles leida veel selliseid värvisõnu nagu apelsin või võilill, millest kumbki ei kuulu rangelt võttes värvinimede semantilisse välja, kuid mille tähenduse kasutamine värvinimena on keelekõnelejale siiski arusaadav. Viimased semantilistele kaartidele enim nimetatud värvinimede hulka muidugi ei mahu, kuna neid on nimetanud vaid üksikud katsealused.

Eesti keeles on üheks huvitavamaks värvimõisteks vesihall, mis paljudes teistes keeltes puudub. Inglise keelde tõlkimisel võiks selle mõiste vasteks olla lihtsalt grey, kuna liitsõnalist mõistet water grey inglise keeleruumis ei esine. Vesihall tundub olevat eesti keele kõnelejate semantilises mälus teiste värvinimede hulgas kindlalt auväärsel kohal, sest seda nimetab väga suur hulk katseisikuid. Semantilisel kaardil jääb vesihall selliste liitsõnaliste värvinimede lähedusse nagu tumehall ja helehall, aga ka hõbedane, süsimust ja kirsipunane, kuna need asuvad paljude keelekasutajate semantilises mälus eesti keeles millegipärast koos (Uusküla, Bimler 2016: 73).

Loetelukatse tulemusi analüüsides selgub, et alati jääb teatud varieeruvus, seda nii katseisikuti, keeleti kui ka eri keelte vahel (Bimler, Uusküla 2018), sest tavaliselt nimetavad katseisikud katse korduse ajal ühe semantilise välja liikmeid kas veidi teises järjekorras või unustavad osa sõnu hoopis. Sama keele kõnelejate loetelud võivad väga suurel määral varieeruda, kuigi sisaldavad sarnaseid kategooria liikmeid, ning eri keelte kõnelejad võivad kasutada mingit konkreetset järjekorda, mille järgi nad on teatud semantilise kategooria liikmed omandanud. Sellist varieeruvust on võimalik uurida nt vaatepunktide analüüsi kasutades (ingl points-of-view analysis) (Bimler, 
Uusküla 2018). Vene keele kõnelejad nimetavad näiteks tihti värvinimesid vikerkaarevärvide järjekorras, sest just nii on neile üldhariduskoolis õpetatud. Vikerkaarevärvide järjest loetlemise poolest eristub vene keel teiste keelte hulgast. Kindlasti tuleb mainida, et eri semantilistesse väljadesse kuuluvate sõnade hulk on katseisikuti erinev. Mõnele meenub rohkem värvisõnu, teisele rohkem loomi, kolmandale linde. Sandra Tiitsoni läbiviidud katsed kinnitasid, et tõlkijad oskavad nimetada palju rohkem värve kui inimesed, kes tõlkimisega igapäevaselt kokku ei puutu (Tiitson 2017).

\section{Kuidas uurida lõhnasõnu ja teisi keeleliselt sildistamata semantilisi kategooriaid?}

Loetelukatse keerulisim küsimus on semantilise/kultuurilise kategooria või tähendusvälja sildistamine mingi sõnaga, nn üldmõistega või katusmõistega (ingl umbrella term), mille alla kõik kategooria liikmed paigutuks. Värvinimed, loomad, linnud, nõud ja kehaosad on kõik ühe konkreetse semantilise kategooria keelelised sildid, üld- ehk katusmõisted, samal ajal kui eesti keeles nagu ka paljudes teistes Euroopas kõneldavates keeltes puudub üldmõiste sellisel semantilisel kategoorial nagu lõhn. Olles üldmõiste, on lõhn samal ajal ka lõhnasõnade kategooria kõige esiletulevam liige (Sutrop 2002; Zurbuchen 2017). Uurija ülesandeks on sellistes loetelukatsetes olla leidlik ning siiski küsida seda, mida uurija teada soovib. Sutrop (2002) küsis oma lõhnasõnavara puudutavates katsetes katseisikutelt „Nimeta, mida võid tunda ninaga”. Sama küsimust kasutas Karin Zurbuchen oma magistritöös, kus ta uuris võrdlevalt eesti ja saksa keele lõhnasõnavara (vt joonist 1).

\section{Kognitiivne esiletulek loetelukatses}

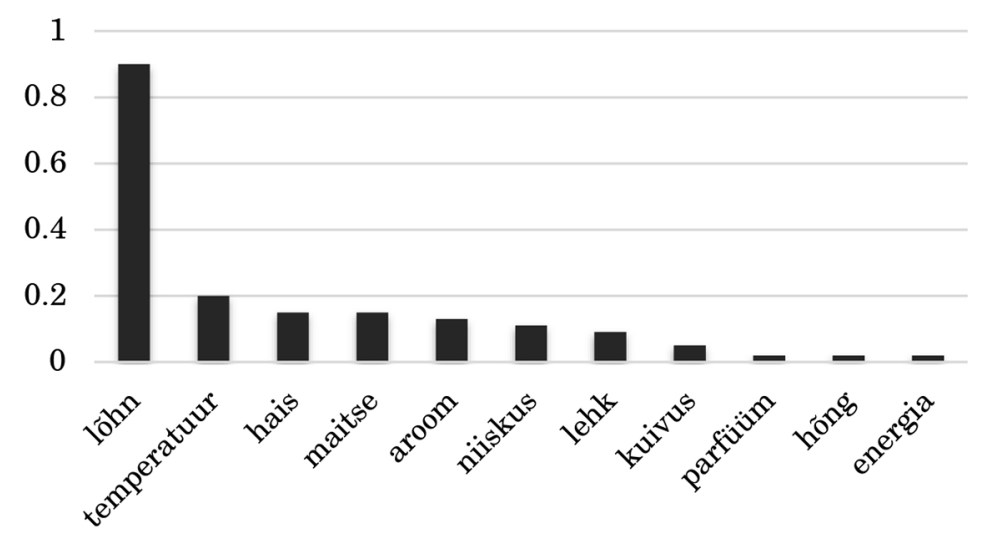

Joonis 1. Eesti keele kõnelejate vastused küsimusele „Nimetage, mida võite tunda ninaga" (Zurbuchen 2017, andmete graafiline esitus autori loal).

Juhul kui uurija ei räägi katseisikute keelt esimese keelena ega tunneta seetõttu kõiki keelelisi aspekte või on lihtsalt vähem leidlik, ei saagi loetelukatset semantilise kategooria uurimiseks kasutada. Lääne-Ghanas kõnelda- 
vas alles kaardistamisjärgus tšakaali (ingl Chakali) keeles puudub üldmõiste värvi tähistamiseks (Brindle 2016: 87-89). Jonathan Brindle loobus seetõttu loetelukatsest, kuna katseisikutelt ei olnud lihtsalt võimalik küsida nii palju värve, kui nad teavad, ning viis läbi ainult värvide nimeandmiskatse. Nimeandmiskatsest järeldub, et tšakaali keeles on värvinimed olemas, mille hulgast eraldas autor teatud parameetreid silmas pidades ka nn põhivärvinimed (Brindle 2016).

\section{Nimeandmiskatse - lihtne ja kasutatav, kuid kas ka piiranguvaba?}

Nimeandmiskatse jaoks on vaja pilte või kirjalikke sõnumeid, mida katseisikutele visuaalseks tuvastamiseks ja nimetamiseks näidatakse. Enamasti küsitakse „Mis on pildil?” või „Mis on kirjas?”. Nimeandmiskatset on hiljuti kasutatud indoeuroopa keelkonna semantilisi suhteid kaardistavas psühholingvistilises uurimuses „Semantiliste süsteemide evolutsioon” (Majid jt 2015), milles selgitati välja, kuidas eri keelte kõnelejad nimetavad värve, nõusid ja kehaosi ning millised on entiteetidevahelised ruumisuhted. Lisaks indoeuroopa keeltele hõlmas projekt ka eesti, udmurdi ja baski keelt. Selle uurimuse raames koguti materjali nimeandmiskatsega, loetelukatset kasutati vaid pilootfaasis ja seda ainult värvinimede väljaselgitamiseks igas keeles. Ilmselt pidasid projektijuhid nimeandmiskatset kõige paremaks meetodiks keeleandmestiku võrdlemisel, sest iga katseisik nimetas ühte stiimulit ühe korra.

Nimeandmiskatse edukaks läbiviimiseks vajabki uurija teatud stiimuleid, mida katseisikutele näidata. Stiimuliteks nimetan nii pildilisi kui ka sõnalisi ärritajaid, mis peavad andma teatud oodatud vastuse. Näiteks kui ekraanile on kirjutatud tähed K-O-E-R, peaksime olema võimelised välja lugema KOER. Pildistiimuli vastus on samuti oodatav, nt punase värvi nägemisel peaksid keelejuhid ütlema „punane” või pildil tassi nähes kirjeldama seda sõnadega „tass”, „kruus” või „jooginõu”, mitte ütlema selle kohta „kauss”. Argikategooriate (ingl ka folk category 'rahvakategooria') (vastandatuna ekspertkategooriatele) (Pajusalu 2009: 8) puhul on alati võimalus, et kategooriate piirid on hägusad ja stiimuli äratundmine keelejuhiti varieeruv. Ühelt poolt ongi inimkeelele omane varieeruvus: mis ühe jaoks on tass, võib teise jaoks tunduda kruusina. Teisalt aga peaksid kõik täiskasvanud keelekõnelejad olema võimelised tegema vahet tassil ja kausil, kuna mõlemal esemel on oma iseloomulikud tunnused, nt kausil ei ole kõrva, millest kinni hoida. Oluline on, et valitud stiimulpilt esindaks vastava kultuuri jaoks kategooria keskset liiget. See aga nõuab uurijatelt suurepärast sihtkeele ja -kultuuri tundmist ning suurtes keeletüpoloogilistes uurimustes on vigade esinemine pea vältimatu, sest igal keelel ja kultuuril võib kategooria parim näide olla teiste keelte ja kultuuride suhtes nihkes (vt Majid jt 2015). 


\section{Nimeandmiskatse semantiku tööriistana}

Juba mainitud argikategooria struktuuri peegeldab eesti keeles hästi värvinimede semantiline tähendusväli, mida on võimalik uurida nii loetelu- kui ka nimeandmiskatsega või nende kahe katse tulemusi kombineerides (vt Uusküla, Sutrop 2011). Loetelukatsega eristuvad esmased värvinimed sinine, punane, kollane, roheline ning akromaatilised värvid, must ja valge, mida mõned katseisikud nimetavad, kuid teised jätavad välja, sest ei pea neid värvideks. Füüsikaliselt kuuluvad värvi ehk värvuse põhikarakteristikute hulka nn värvitoon ehk värv, värvi heledus (või tumedus) ning värvi küllastus (Tammert 2017). Tänu eesti produktiivsele liitsõnamoodustusele saab kõiki neid värvide omadusi keeleliselt väljendada. Eesti rahvapäraseid ja murdelisi värvinimesid on põhjalikult käsitlenud Vilja Oja (2007), lisaks on uuritud soome-ugri keeli võrdlevalt liitsõnamoodustuse seisukohalt (Uusküla jt 2012). Eesti keeles saame värvitoonile või värvile viidates rääkida punasest, sinisest või kollasest, värvi heledus- ja tumedusskaalal saame liikuda, valides värvisõna ette sobiva adjektiivi, nt heleroheline või tumeroheline, mille vahele jääb roheline (st mitte rohelise hele ega tume teisendus, vaid $\mathrm{nn}$ pärisroheline). Küllastuse skaalal liikudes on eesti keele kõnelejal võimalik rääkida eredatest või erksatest värvidest, nt ereroheline või erkroheline, ja skaala vastandpoolele jäävatest tuhmidest toonidest, nt tuhmroheline või hallikasroheline.

Lisaks võib värvinimedel olla peidetud semantilisi omadusi, mida keeleliselt eraldiseisva markeriga ei tähistata ja mille tegelikku tähendust aitab välja selgitada kombineeritud metoodika, mille ühe osana võib kasutada ka nimeandmiskatset. Carole Biggam (2012) on oma värvisemantikat puudutavas monograafias just viidanud sellistele peidetud omadustele, mida ta on nimetanud „teisteks välisilme omadusteks” (ingl other aspects of appearance). Rääkides asja omadusest, käsitleme tegelikult seda, kuidas miski meile näib või tundub. Värvide puhul on värvide omadustest rääkimine igati mõistuslik ja teretulnud. Tegemist võib olla omadustega, mida ei ole võimalik ükskõik millisel värvikaardil või värvitahvlil näidata, olenemata valitud värvisüsteemist. Vaatamata mõnele puudusele, millele järgnevalt osutan, võib siiski väita, et värvistiimulite näitamine nimeandmiskatses toimib üsna hästi ning nimeandmiskatset saab kasutada ka nende keelte uurimisel, milles puudub üldmõiste värvi tähistamiseks (Brindle 2016). Seega on nimeandmiskatse mõnes mõttes kasutatavamgi kui loetelukatse ning tähenduseuurijale vajalik töömeetod.

\section{Stiimulite valikust nimeandmiskatses}

Kuigi stiimulist tingitud tõenäoliselt valede vastuste saamine ei kehti ainult värvide semantilise välja kohta, võib siiski just sellest tuua kõige rohkem näiteid. Uurijad peaksid püüdma võimalusel vältida olukorda, kus tulemus sõltub stiimuli valikust. Ometi ei ole katseisikute antavad vastused alati oodatavad ning ei saa ka välistada, et uurija küsimustest ja palvetest saadakse lihtsalt valesti aru. Alati ei tööta päris teadmatute katsealuste kasutamine, sest uurija on mõelnud hoopis mõnele muule vastusele, mida ta soovib katseisikute 
semantilisest mälust kätte saada, seega on enne materjali kogumist kindlasti otstarbekas läbi viia proovikatseid. Järgnevalt toon mõned näited.

Liivi Hollmani (2011) uurimusest selgub, et eesti viipekeeles kasutatakse punase tähistamiseks kahte erinevat viibet, kuid ainult ühte neist saab kujutada värvistiimulil. Teine viibe viitab punastele vedelikele, seega kitsendab nimeandmiskatse oluliselt värvide tähistamiseks kasutatavate viibete arvu, kuigi loetelukatses kasutavad keelejuhid mõlemat viibet. Värvistiimulite valik on seega värvinimede uurimisel primaarse tähtsusega. Sageli peab uurija arvestama, et lisaks eespool nimetatud värvi põhikarakteristikutele võivad uuritavas keeles rolli mängida teised varjatud semantilised omadused, nagu tahke ja vedel (Hollman 2011), matt ja läikiv pind (Uusküla, Eessalu 2018) või see, kas värv tundub meile mahlakas või närtsinud (Conklin 1955).

Matt või läikiv värvistiimuli pind võib kujuneda oluliseks kitsenduseks värvinimede uurimisel. Kui kasutada nimeandmiskatses stiimulitena mati pinnaga Ostwaldi värvisüsteemil põhinevaid Color-aid korporatsiooni värvikaarte, nimetatakse igas uuritud keeles piisavalt värvisõna must (Uusküla 2006; Uusküla, Eessalu 2018). Kui aga värvistiimuliteks on läikiva pinnaga Munselli süsteemi värvikaardid, mida kasutati Euroopa keelte semantiliste süsteemide uuringus (EoSS), on tulemused üllatavad. Mustale värvistiimulile koodiga N2 antud värvinimede hulgas domineeris must harva, selle asemel pakuti tumehalli, tumepruuni, aga isegi tumerohelist ja tumelillat (Uusküla, Eessalu 2018). Valimi moodustasid 14 Euroopas kõneldavat indoeuroopa, soome-ugri ja altai keelkonda kuuluvat keelt ning kõigi keelte tulemused olid N2 värvikoodiga stiimuli nimetamisel sarnased, kuigi tegemist on kindlasti musta värviga. Teiste värvidega selliseid semantilisi kõrvalekaldeid ei täheldatud, mistõttu võib järeldada, et must värv sisaldab kõrvaltähendust matt ehk lihtsamalt öeldes: must on ainult matt, mitte läikiv must (Uusküla, Eessalu 2018: 43).

Piirangutega seostub ka ungari kahe punase piros ja vörös kasutus (Bogatkin-Uusküla, Sutrop 2005; Uusküla 2011), mille semantika sõltub kontekstist. Vörös tähistab ungari keeles nn kurja ja kommunistlikku punast, samal ajal kui piros on neutraalne ning isegi positiivse konnotatsiooniga. Kuidas võib uurija kindel olla, et värvistiimulite valik, mida keelejuhtidele näidatakse, üldse sisaldab sellist värvi nagu vörös? On teada, et ungari värvinime vörös kollokaatidena esinevad teised sõnad kui värvinimel piros (Uusküla 2011: 151-152). Brent Berlini ja Paul Kay (1969) teooria kohaselt võib ungari keeles põhivärvinimeks lugeda ainult värvinime piros, mida saab kasutada enamikus neutraalsetes kontekstides.

Kuigi ungari ja türgi keel pole omavahel selles mõttes võrreldavad, et ungari keeles on ainult üks punase värvi kategooria, türgi keeles võime aga täheldada kategooria jagunemist kahe värvinime vahel, on siiski alust neid võrrelda just nimeandmiskatse stiimulite valikut silmas pidades. Kaidi Rätsep on põhjalikult käsitlenud värvide kategoriseerimist ja nimetamist türgi keeles, milles esineb sarnane probleem (Rätsep 2011). Sinise kategooria jaguneb türgi keeles kaheks, kus seda tähistatakse vastavalt värvinimedega lacivert ja mavi. Rätsep täiendas oma stiimulivalikut, lisades standardsete värvitahvlite hulka (vt Davies, Corbett 1995) mitu sinist, seda nii heledast kui ka tumedast spektrialast, et selgitada välja, kas stiimulite lisamine muudab värvinime lacivert 
staatust. Rätsepa andmetel on türgi keeles siiski ainult üks põhikategooria sinise jaoks, mavi, ning lacivert on kasutusel sinise alamkategooriana.

Ehk kitsendab värvitahvlite kasutamine liialt katseisikute keelekasutust? Seda, kas on olemas paremaid viise värvide tähistajate kohta infot koguda, on siiski raske öelda. Üheks võimaluseks on välitöödel ja/või keelelaboris läbiviidud katsete võrdlemine korpusanalüüsiga, kust on võimalik leida värvinimede kasutuskonteksti ja selle järgi hinnata värvikategooria piire. Kuid korpusanalüüs ei ole värvitähistajate leidmiseks kindlasti mitte parim viis.

Värviuurijate $^{2}$ katses on enamkasutatavateks värvisüsteemideks olnud Munselli ja Ostwaldi värvisüsteemid. Ostwaldi värvisüsteemi kasutatakse Color-aidi värvikaartidel, see põhineb omakorda NCS (Natural Color System) värvisüsteemil (värvisüsteemide kohta vt Uusküla, Sutrop 2011; Tammert 2017). Kui soovime saada täielikku infot värvinimede semantika kohta, võib kasulikuks osutuda mitme meetodi kombineerimine. Värvikategooria uurimiseks sobib kasutada klassikaliseks kombinatsiooniks saanud loetelukatse ja nimeandmiskatse (Davies jt 1992; Davies, Corbett 1995) kõrval ka sorteerimiskatseid või assotsiatsioonikatseid (nt Roberson jt 2005; Davies 2011; Bimler jt 2015; Bimler, Uusküla 2017; Prado-León, Rosales-Cinco 2011). Sorteerimiskatses palutakse katseisikute abi stiimulite, nt värvikaartide rühmitamisel harilikult sarnasuse alusel. Sorteerimiskatsed annavad aimu, kus paiknevad kategooria piirid, ja võivad viidata sellele, et inimesed kasutavad kategoriseerimisprotsessis siiski väga suurel määral oma emakeelt, nagu selgus sinise spektriala rühmitamisel kuues keeles - inglise, eesti, vene, itaalia, leedu ja udmurdi keeles (Bimler, Uusküla 2017).

Lisaks värvidele, mille näitamine on ühtaegu nii kerge kui ka keeruline, kuid enamasti saadakse siiski parim tulemus vastava referendi kohta, võib näiteid tuua ka ruumisuhete tähendusväljast. Eespool mainitud Max Plancki psühholingvistika instituudi EoSS projektis moodustasid ühe uuritava semantilise kategooria just ruumisuhted: uuriti nimelt, kus paikneb mingi objekt teise või teiste objektide suhtes. Pildistiimulid kujutasid nt tassi laual/laua peal või riidenagi seinal/seina küljes. Eesti keeles on vastavate suhete kujutamiseks teatavasti grammatiliselt kaks võimalust: kaassõna ja käändega, indoeuroopa keeltes enamasti aga vaid üks. Kuna projekt uuris esmalt indoeuroopa keelte semantilisi süsteeme ja nende arengut ning eesti keel lülitati projekti hiljem, valiti ka stiimulpildid indoeuroopa keelte grammatilisse konteksti sobituvalt. Katsetes kasutati projektijuhtide seatud kriteeriume järgides keelekaugeid katseisikuid, kes said suurepäraselt hakkama värvide, anumate (inglise keeles kasutati semantilise välja jaoks üldmõistet containers $^{3}$ ) ja kehaosade nimetamise ja määramisega (Majid jt 2011), jäädes aga hätta ruumisuhete kirjeldamisega viisil, kuidas neil paluti vastata. Indoeuroopa

${ }^{2}$ Värviuurijatena käsitlen siin uurijaid, kes tegelevad värvide nimetamise ja tunnetamise uurimisega. Nendeks on enamasti kognitiivsed keeleteadlased, psühholingvistid, psühholoogid ja taju-uurijad.

${ }^{3}$ Sandra Tiitson (2017) kordas EoSS projekti katseid. Ta kaasas oma uurimusse neli semantilist välja: kehaosad, värvinimed, loomad ja nõud. Sõna containers otsustas ta asendada sõnaga nõud, kuna see tundub eesti keele kõnelejale vähem abstraktne ja seega arusaadavam. Samas nendib Tiitson, et semantilisse välja nõud kuuluvad eesti keeles ka muud kui kopsikud-anumad, nt noad, kahvlid, lusikad, mida Tiitsoni loetelukatsetes ka esines. 
keeltega võrdlusaluse tekitamiseks oleks olnud ideaalne, kui kõik eesti katseisikud oleksid kasutanud ruumisuhete kirjeldamisel kaassõna, tegelikkuses aga ütlesid mitmed keelejuhid, et tass on laual, mitte tass on laua peal; karp on kotis, mitte karp on koti sees; stiimuli lipp on masti otsas või masti küljes vastuseks öeldi lihtsalt lipp on vardas. Ruumisuhete katse hilisemat kodeerimist raskendas see, et vaatamata korduvatele uurijapoolsetele märguannetele kirjeldada pildil nähtavat terviklausega, kasutasid mõned katsealused üksikfraasi või isegi üksikut sõna, nt laual, vaasis, küljes jne.

Lisaks ruumisuhete kirjeldamisraskustele tekkis mõningane segadus ka kehaosade nimetamisel, mille stiimulina kasutati sootunnusteta mehe keha kontuuri (Enfield jt 2006). Figuuri jalad asetsesid pildil sellise nurga all, mis ei võimaldanud katseisikutel aru saada, kas figuuri on kujutatud eest või tagant. Seega paigutati vahetevahel naba figuuri seljaosale. Segadusi tekitas ka käe ja jala osade nimetamine, nt sääre kohal nimetati hoopis reit ning suure sagedusega nimetati nii käsivart kui ka jalalaba ehk stiimulite näitamine ületas nende keelendite tavakasutust.

\section{Kokkuvõte}

Katselise semantika ohtudest ja kitsaskohtadest on Eestis varem kirjutanud ka Jane Klavan, Ann Veismann ja Anni Jürine (2013). Nad viitavad õigesti eel- või järelhäälestusele (ingl semantic priming), ${ }^{4}$ mis katsete läbiviimisega kaasneb. Samas on teada, et eri meetodite kasutamine võib anda mõnevõrra erinevaid tulemusi (vt Anishchanka, Verheyen 2017). Tõenäoliselt sobib loetelukatse ja nimeandmiskatse kombineerimine hästi selliste semantiliste kategooriate uurimiseks nagu värvinimed või lõhnasõnad (vt Zurbuchen 2017). Kui loetelukatses nimetavad katseisikud esmalt kategooria tüüpilisi liikmeid ehk sõnu, mis neile mingil põhjusel just küsitletud semantilisest väljast esimesena meenuvad, siis nimeandmiskatsega uuritakse referendi ja tähistaja suhet ehk millise konkreetse stiimuli kohta mingit keelelist tähistust kasutatakse. Kuigi värvide semantilisest väljast meenuvad tavaliselt esimesena värvinimed punane, sinine, kollane ja roheline, olenemata keelest (Uusküla, Bimler 2016), võivad eri keelte kõnelejad ometi tajuda täiesti erinevalt, milline võiks olla värvinimedele punane, sinine, kollane ja roheline vastav värvus (Uusküla 2006). Uuritavast keelest, uurimismeetodist, -ainesest, hüpoteesist, eesmärgist, katse läbiviimise kohast ja lõpuks ka uurija isikust oleneb tihti, kas loetelu- ja nimeandmiskatsed viiakse läbi koos või eraldi.

Konverentsisarja „Teoreetiline keeleteadus Eestis” konverentsil „Kvantitatiivne pööre keeleteaduses - mis saab teooriast” (23.-24. XI 2017) küsisid konverentsikorraldajad kõigilt esinejatelt küsimuse: mis saab teooriast? Õige

\footnotetext{
${ }^{4}$ Terminit semantic priming on eesti keelde erinevalt tõlgitud. Eestikeelses kirjanduses leidub nimisõna praiming ja viidatakse praimimisele. Olen oma psühholingvistika loengutes arutanud tõlketudengitega, et termini vasteks sobiks näiteks eelhäälestus või järelhäälestus, kuna lisaks võorapärasele kõlale viitab praimimine tegelikult sellele, et katseisikut häälestatakse millekski. Sarnaselt võib mõni konkreetne stiimul (sõna, lause) eelhäälestada katseisikuid teatud vastust andma. Mõnikord võib tegu olla ka tagantjärele häälestamisega ja siis oleks otstarbekas kasutada järelhäälestust.
} 
vastus sellele küsimusele oleks, et teooriast ei saa midagi, sest teooria ja kvantitatiivsed meetodid võivad hästi eksisteerida käsikäes, üks ei välista teist, sest mingit vastandust nende vahel sisuliselt ei ole. Teooria jääb igal juhul, sest iga katse analüüsimiseks on vaja sobivaid meetodeid ning tervikpildi mõistmiseks tulemuste teooriakohast tõlgendamist, ilma milleta pole katse tulemustel ka mingit raamistikku ega väärtust laiemas teaduslikus kontekstis. Küll aga tahaks julgustada keele- ja taju-uurijaid tähele panema iga katsetüübi voorusi ja vigu, et oma materjali kriitilise pilguga üle vaadata ja õigesti tõlgendada. Igatahes selleks, et võiks sündida midagi uut, on uurijal vaja mõelda kastist väljapoole. Seega on katseliste meetodite kasutamine kindlasti mõnevõrra parem introspektsioonist. Alati ei olegi võimalik detailselt läbi mõelda kõiki kitsaskohti, mis uurimise käigus võivad ilmneda. Tähtis on, et katseid julgetaks teha ka siis, kui ei saada soovitud tulemusi või kui need ilmnevad alles materjali analüüsimisel.

\section{Kirjandus}

Aitchis o n, Jean 1994. Words in the Mind: An Introduction to Mental Lexicon. Oxford: Blackwell.

Aloi a, Mark S., G o u rovitch, Monica L., W e in berger, Daniel R., Gold berg, Terry E. 1996. An investigation of semantic space in patients with schizophrenia. - Journal of International Neuropsychological Society, kd 2, nr 4, lk 267273.

Anishchanka, Alena, Verheyen, Steven 2017. Experimental and corpusderived evidence for color term basicness: bridging the disciplinary divide. - The 14th International Cognitive Linguistics Conference: Linguistic Diversity and Cognitive Linguistics (ICLC14), Tartu, 10-14 July, 2017. Book of Abstracts.

B e r li n, Brent, Ka y, Paul 1969. Basic Color Terms: Their Universality and Evolution. Berkeley: University of California Press.

Biggam, Carole 2012. The Semantics of Colour. A Historical Approach. Cambridge: Cambridge University Press.

Bi m l e r, David, Kirkl a nd, John, U u s küla, Mari 2015. Applying points-of-view analysis to individual variations in colour sorting data. - Journal of Cognition and Culture, kd 15, nr 1-2, lk 87-108.

Bimler, David, Uusküla, Mari 2017. A Similarity-based cross-linguistic comparison of basicness and demarcation of „blue” terms. - Color Research and Application, kd 42, nr 3, lk 362-377.

Bimler, David, Uusküla, Mari 2018. Individual variations in color-concept space replicate across languages. - Journal of the Optical Society of America, kd A 35, nr 4, lk B184-B191.

B ogatkin-Uusküla, Mari, Sutrop, Urmas 2005. Kas ungari keeles on kaks punase värvi põhinime piros ja vörös? - Emakeele Seltsi aastaraamat 50 (2004). Tallinn: Emakeele Selts, lk 93-110.

Brindle, Jonathan 2016. Color basicness in Chakali. - Colour Language and Colour Categorization. Toim Geda Paulsen, Mari Uusküla, J. Brindle. Newcastle: Cambridge Scholars, lk 87-114. 
Cha n, Agnes S., Butter s, Nelson, Salm on David P. 1997. The deterioration of semantic networks in patients with Alzheimer's disease: A cross-sectional study. - Neuropsychologia, kd 35, nr 3, lk 241-248.

Conklin, Harold 1955. Hanonoo color categories. - Southwestern Journal of Anthropology, kd 11, lk 441-446.

Davies, Ian R. L. 2011. A study of colour grouping in three languages: A test of the linguistic relativity hypothesis. - British Journal of Psychology, kd 98, nr 3, lk 433-452.

Davies, Ian, Corbett, Greville 1995. Linguistic and behavioural measures for ranking basic colour terms. - Studies in Language, kd 19, nr 2, lk 301-357.

Davies, Ian, MacDermid, Catriona, Corbett, Greville, McGurk, Harry, Terrett, David, Terrett, Tiny, S ow d e n, Paul 1992. Color terms in Setswana: A Linguistic and perceptual approach. - Linguistics, kd 30, nr 6, lk 1065-1103.

Eessalu, Martin 2012. The categorization of the Estonian domain of „musical instruments" - listeners vs musicians and the comparison of basic levels. ESUKA/JEFUL, kd 3, nr 1, lk 227-241.

Eessalu, Martin 2013. Elusloodus eesti keeles: prototüüpsus ning abstraktse taksonoomia konstrueerimine. Magistritöö. Tartu Ülikool.

Eessalu, Martin, Uusküla, Mari 2013. The special case of beige: a crosslinguistic study. - Colour and Colorimetry: Multidisciplinary Contributions, $\mathrm{kd}$ IX B. Toim Maurizio Rossi. Milano: Maggioli Editore, lk 168-176.

EKAS = Eesti keele assotsiatsioonisõnastik. http://www.eki.ee/ ene/kodanikuteadus/assotsiatsioonid.html (13. II 2018).

Enfield, Nick, Majid, Asifa, van Staden, Miriam 2006. Cross-linguistic categorization of the body: Introduction. - Language Sciences, kd 28, nr 2-3, lk 137-147.

Hollm an, Liivi 2011. Põhivärvinimed eesti viipekeeles. - Värvinimede raamat. Toim Mari Uusküla, Urmas Sutrop. Tallinn: Eesti Keele Sihtasutus, lk 89-113.

Klavan, Jane, Veismann, Ann, Jürine, Anni 2013. Katselised meetodid tähenduse uurimisel. - ESUKA/JEFUL, kd 4, nr 1, lk 17-34.

Kl e m m, Jürgen 2013. Tänapäeva eesti keele sugulussõnavara. Magistritöö. Tartu Ülikool. http://hdl.handle.net/10062/30894

Majid, Asifa, Jordan, Fiona, Dunn, Michael 2011. Evolution of Semantic Systems Procedures Manual. Developed for the EoSS Project. Nijmegen: Max Planck Institute for Psycholinguistics.

Majid, Asifa, Jor d a n, Fiona, D u n n, Michael 2015. Semantic systems in closely related languages. - Language Sciences, kd 49, lk 1-18.

Mä n n i k, Anna-Liisa 2016. Sõnade assotsiatsioonid eesti ja inglise keeles. Magistritöö. Tallinna Ülikool.

Oj a, Vilja 2007. Colour naming in Estonian and cognate languages. - Anthropology of Color: Interdisciplinary Multilevel Modeling. Toim Robert E. MacLaury, Galina Paramei, Don Dedrick. Amsterdam-Philadelphia: John Benjamins, lk 189-209.

Paju s alu, Renate 2009. Sõna ja tähendus. Tallinn: Eesti Keele Sihtasutus.

Prado-León, Lilia Roselia, Rosales-Cinco, Rosa Amelia 2011. Effects of lightness and saturation on color associations in the Mexican population. - New Directions in Colour Studies. Toim Carole P. Biggam, Carole Hough, Christian Kay, David R. Simmons. Amsterdam: John Benjamins, lk 389-394. 
Roberson, Debi, I an R. L. Davies, Corbett, Greville G., Vandervyver, Marieta 2005. Free-sorting of colors across cultures: Are there universal grounds for grouping? - Journal of Cognition and Culture, kd 5, nr 3, lk 349-386.

$R$ äts e p, Kaidi 2011. Preliminary research on Turkish basic colour terms with an emphasis on blue. - New Directions in Colour Studies. Toim Carole P. Biggam, Carole Hough, Christian Kay, David R. Simmons. Amsterdam: John Benjamins, lk 133-145.

S m ith, J. Jerome 1993. Using ANTHROPAC 3.5 and a spreadsheet to compute a free-list salience index. - Cultural Anthropology Methods Journals, kd 5, nr 3, lk 1-3.

Sutrop, Urmas 1995. Eesti keele põhivärvinimed. - Keel ja Kirjandus, nr 12, lk 797-808.

Sutrop, Urmas 1998. Basic temperature terms and subjective temperature scale. - Lexicology, kd 4, nr 1, lk 60-104.

Sutrop, Urmas 2001. List task and a cognitive salience index. - Field Methods, kd 13, nr 3, lk 263-276.

Sutrop, Urmas 2002. The Vocabulary of Sense Perception in Estonian: Structure and History. (Opuscula Fenno-Ugrica Gottingensia 8.) Frankfurt am Main: Peter Lang.

Sutrop, Urmas 2011. Loetelukatse ja kognitiivse esiletuleku indeks. Põhivärvinimed eesti viipekeeles. - Värvinimede raamat. Toim Mari Uusküla, U. Sutrop. Tallinn: Eesti Keele Sihtasutus, lk 51-61.

Zurbuchen, Karin 2017. Eesti ja saksa värvi- ja lõhnasõnade võrdlev analüüs empiirilise uurimuse varal. Magistritöö. Tallinna Ülikool.

T a m m ert, Marje 2017. Värviteooria. Tallinn: Aimwell.

Tiitson, Sandra 2017. Tõlkijate ja mittetõlkijate kategooriate võrdlus nelja semantilise välja põhjal. Magistritöö. Tallinna Ülikool.

Uusküla, Mari 2006. Distribution of colour terms in Ostwald's colour space in Estonian, Finnish, Hungarian, Russian and English. - Trames, kd 10, nr 2, lk 152-168.

Uusküla, Mari 2007. The basic colour terms of Finnish. - SKY Journal of Linguistics, kd 20, lk 367-397.

Uusküla, Mari 2011. Terms for red in Central Europe: An areal phenomenon in Hungarian and Czech. - New Directions in Colour Studies. Toim Carole P. Biggam, Carole Hough, Christian Kay, David R. Simmons. Amsterdam: John Benjamins, lk 147-160.

U u s kül a, Mari, Bi m l er, David 2016. From listing data to semantic maps: Crosslinguistic commonalities in the cognitive representation of colour. - Folklore: The Electronic Journal of Folklore, kd 64, lk 57-90.

Uusküla, Mari, E es s alu, Martin 2018. Glossy black is not actually 'black': Evidence from psycholinguistic colour naming studies in 14 European languages. Cultura e Scienza del Colore / Color Culture and Science Journal, kd 9, lk 39-44.

Uusküla, Mari, Hollman, Liivi, Sutrop, Urmas 2012. Basic colour terms in five Finno-Ugric languages and Estonian Sign Language: A comparative study. - ESUKA/JEFUL, kd 3, nr 1, lk 47-86.

U u s küla, Mari, Su tr o p, Urmas 2007. Preliminary study of basic colour terms in modern Hungarian. - Linguistica Uralica, nr 2, lk 102-123. 
Uusküla, Mari, Sutrop, Urmas (toim) 2011. Värvinimede raamat. Tallinn: EKSA.

V a in ik, Ene 2002. Emotions, emotion terms and emotion concepts in an Estonian folk model. - Trames, kd 6, nr 4, lk 322-341.

Vainik, Ene 2006. Intracultural variations of semantic and episodic emotion knowledge in Estonian. - Trames, kd 6, nr 1, lk 169-189.

Vei s m a n n, Ann 2008. Eesti kaassõnade tähenduste kirjeldamise probleemidest. - Keel ja Kirjandus, nr 5, lk 335-352.

Vejdemo, Susanne 2017. Triangulating Perspectives on Lexical Replacement: From Predictive Statistical Models to Descriptive Color Linguistics. Stockholm: Stockholm University.

Weller, Susan, Rom ney, Kimball 1988. Systematic Data Collection. California: Sage.

Mari Uusküla (snd 1980 Bogatkin), PhD, Tallinna Ülikooli lingvistika ja tõlketeaduse dotsent,muuskyla@tlu.ee

\section{List task and naming task as psycholinguistic methods: Advantages and pitfalls}

Keywords: research methods, empirical methods, data collection, semantics, colour terms, spatial relations

Both the list task (elicitation task or listing task) and the naming task are widely used in psycholinguistics, cognitive linguistics and anthropological linguistics as well as in social sciences and clinical testing for Alzheimer's Syndrome. Both methods are easily adaptable to linguistic and other phenomena, applicable without complicated research settings and effortless for researchers to use on research site. Due to the ease they can be used on large numbers of participants who agree to contribute their knowledge voluntarily. Empirical methods can give different results than introspection or corpus analysis. However, both list task and naming tasks have advantages and disadvantages which are not immediately obvious. One of the advantages is that list and naming tasks can be approached by bottom-up analysis. There are disadvantages as well. Listing cannot be performed if a language lacks an umbrella term for a particular semantic field, e.g. smell, where 'smell' itself belongs to the basic-word inventory of the smell domain. In these instances, researchers need to be creative or alternatively abandon the list task altogether, as is known from the literature for languages which do not possess a word for 'colour'. Conversely, with naming tasks, researchers need to be careful when selecting appropriate stimuli which might be especially challenging for large-scale typological studies where concepts might differ from language to language. This article contains multiple examples from Estonian and other languages which refer, on the one hand, to language-specific untranslatable phenomena, and on the other hand, bring out those cases where participants have misunderstood instructions or misinterpreted the stimuli due to their complexity.

Mari Uusküla (b. 1980 Bogatkin), PhD, Tallinn University, Associate Professor of Linguistics and Translation Theory, muuskyla@tlu.ee 